\title{
INSIDE PAPUA: THE POLICE FORCE AS COUNTERINSURGENTS IN POST-REFORMASI INDONESIA
}

\section{Emirza Adi Syailendra}

Indonesia is witnessing an increasing number of activities by the Free Papuan Movement (Organisasi Papua Merdeka, OPM), both violent and nonviolent, designed to undermine Indonesia's legitimacy in Papua. OPM's political goal is to separate West Papua from the Republic of Indonesia. West Papua, which comprises Papua province and West Papua province, has endured low-level violent resistance from OPM since 1969. This resistance began occurring more frequently after the controversial "act of free choice," a referendum process that resulted in Papuan representatives' unanimous decision to stay within Indonesia's sovereignty. But some view the referendum itself as fraudulent. ${ }^{1}$ Between 2009 and 2014, according to the Papua Regional Police's 2015 Threat Perception Report, there were 166 cases of violence involving the OPM. From 2006 to 2014, civilians were the victims of most of the armed violence, accounting for fifty-nine fatalities, followed by personnel (twentyseven) and the military (twenty-two). ${ }^{2}$ This violence culminated in Enden Wanimbo's

Emirza Adi Syailendra is a research analyst at the Institute of Defence and Strategic Studies (Indonesia Programme), S. Rajaratnam School of International Studies, Nanyang Technological University, Singapore. ${ }^{1}$ See Saltford's study on the failure of the United Nations to oversee Papua's referendum process. John Saltford, "United Nations Involvement with the Act of Self-Determination in West Irian (Indonesian West New Guinea), 1968-1969," Indonesia 69 (April 2000): 71-92.

${ }^{2}$ Cases of violence included armed clashes between insurgents and counterinsurgents. Other incidents involved burning property, flag hoisting to deny openly Indonesia's sovereignty (which is often followed by social unrest), and taking a security personnel's weapon away. See Direktorat Intelijen Keamanan (Dirintelkam) Polda Papua [Directorate of Intelligence and Security of Papua Regional Police], Hakekat Ancaman Kelompok Kriminal Bersenjata (KKB) dan Kelompok Kriminal Politik (KKP) di Papua Tahun 2015 [Threat perception of armed criminal groups (KKB) and political criminal group (KKP) in Papua 2015] (Jayapura: 
declaration of war in 2015. Wanimbo, a commander of the OPM's National Liberation Army (Tentara Pembebasan Nasional, TPN), one of the separatist groups in West Papua, announced "a total revolutionary war" against the state security apparatus in Papua. ${ }^{3}$

The burgeoning violence was accompanied by attempts to rally support from states and nonstate actors overseas, especially from Melanesian Spearhead Group (MSG) members, such as Papua New Guinea and Fiji. With the help of these countries, concerns about Papua's independence and human-rights abuses by Indonesia were actively promoted at the international forum, such as Vanuatu's action in early 2015 to raise the issue of Papuan independence at the United Nations General Assembly. ${ }^{4}$ In 2016, this issue also attracted international attention after Jeremy Corybn, opposition leader in the United Kingdom, called Indonesia's presence in West Papua illegitimate and invasive, and suggested an independence vote. ${ }^{5}$ Corbyn's remarks sparked discussions among Indonesia's citizenry, and prompted many open letters from citizens and public officials declaring such allegations false. ${ }^{6}$

Responding to OPM's escalating quest for independence, Joko Widodo (Jokowi), the seventh president of the Republic Indonesia, focused enormous attention on the region. He began visiting Papua frequently; advocated for high-profile, flagship projects in the region; and ventured to Pacific Rim countries to appeal for support for Indonesia's sovereignty over Papua. ${ }^{7}$ This attention is warranted, given West Papua's vital importance to Indonesia in terms of its economic contributions and as a strategic buffer from the threat of foreign intrusion. At more than 443,000 square kilometers, Papua is the largest island in Indonesia and contains resources of considerable value. ${ }^{8}$ Maintaining stability in Papua is important to Indonesia's economy. Indonesian leaders must avoid a repeat of the bloody 1999 East Timor separation, a crisis marked

Polda Papua [Papua Regional Police], 2015), 3 (hereafter Dirintelkam Polda Papua, Hakekat Ancaman KKB dan KKP di Papua Tahun 2015).

${ }^{3}$ Banjir Ambarita, "OPM Declares Open War on Security Forces, Non-Papuan Civilians," Jakarta Globe, May 22, 2015, http://jakartaglobe.beritasatu.com/news/opm-declares-open-war-security-forces-nonpapuan-civilians/, accessed July 28, 2016.

4 "West Papua-Return to Melanesia," Pacific.Scoop, April 10, 2015, http://pacific.scoop.co.nz/2015/04/ west-papua-return-to-melanesia/, accessed July 28, 2016.

${ }^{5}$ Helen Davidson, "Jeremy Corbyn on West Papua: UK Labour leader Calls for Independence Vote," The Guardian, May 6, 2016, https://www.theguardian.com/world/2016/may/06/jeremy-corbyn-on-westpapua-uk-labour-leader-calls-for-independence-vote, accessed July 28, 2016.

${ }^{6}$ For examples, see: Muhammad Zulfikar Rakhmat, "An Open Letter to Jeremy Corbyn from Indonesia," Huffington Post, May 9, 2016, http://www.huffingtonpost.co.uk/muhammad-zulfikar-rakhmat/an-openletter-to-jeremy-_b_9864254.html, accessed July 28, 2016.; and "Jelaskan Papua, Menteri Luhut Temui Tokoh Gereja Inggris" [Explaining Indonesia's position on Papua, Coordinating Minister Luhut had had meeting with prominent church figures in England]," Tempo, May 15, 2016, https://m.tempo.co/read/ news/2016/05/15/117771115/jelaskan-papua-menteri-luhut-temui-tokoh-gereja-inggris, accessed July 28, 2016.

${ }^{7}$ Emirza Adi Syailendra, "Papua Region under Jokowi: New President, New Strategies," RSIS Commentary 110 (May 7, 2015), https://www.rsis.edu.sg/rsis-publication/rsis/co15110-papua-region-under-jokowi-newpresident-new-strategies/, accessed May 14, 2015.

${ }^{8}$ Papuan forest is the largest in Indonesia, accounting for more than 49 million hectares. Having 45 percent of national copper reserves located at the region, Papua is also important for the national mining sector. See Kementerian Perencanaan Pembangunan Nasional-BPPN (Ministry of National Strategic Planning), Rencana Pembangunan Jangka Menengah Nasional 2015-2019, Buku III, Agenda Pembangunan Wilayah [National Development Planning 2015-2019, 3rd edition, Regional Development Agenda]" (Jakarta: BPPN, 2014). 
by thousands of deaths and hundreds of thousands of displaced persons, and which crippled Indonesia's regional diplomatic credentials. ${ }^{9}$

One aspect of Indonesia's maintaining its territorial integrity from multiple insurgent groups following its transition to democracy has been the gradual shift of counterinsurgency forces from military oversight to a law enforcement framework. This approach focuses on a combination of local policing and building support and connections with local inhabitants, in order to extract information about insurgents and sever links between rebels and their support base. This marks a departure from Suharto's proactive and punitive approaches, led by the military, especially the army (Tentara Nasional Indonesia Angkatan Darat, TNI AD). Suharto's army attracted many critics from the international community for using abusive methods, such as torture and extra judicial executions, against the rebels and the local populace. ${ }^{10}$

Today the Indonesian Force (Polisi Republik Indonesia, POLRI) spearheads counterinsurgency operations by collaborating with related security agencies, primarily the Indonesian military (Tentara Nasional Indonesia, TNI). Under the auspices of POLRI, a counterinsurgency effort in West Papua against the OPM was launched, called Operasi Aman Matoa, or Operation Securing Papua. ${ }^{11}$ The project, an armed crime-prevention operation that has been running annually since 2010 , is led by the Counterinsurgency Task Force of the Papua Regional Police. Operasi Aman Matoa signifies an important transition toward democracy, as it moved the philosophy of counterinsurgency toward a rule-of-law approach, which marked an attempt to depart from previous brutal military operations. At least in theory, empowering police is a critical component of counterinsurgency's rule-of-law trinity of "cops, courts, and corrections." 12

Within the abovementioned context, it is interesting to study the impact of political changes in Indonesia on its approaches to maintaining sovereignty. I wrote this piece from the perspective of the state security apparatus, as evolving scholarship pays scant regard to the fundamental role the police force performs in Papua-both in pacifying insurgents and its contribution to instability in the region. ${ }^{13}$ Much has been written about violent conflict. However, major studies on Papua have been written

\footnotetext{
${ }^{9}$ Ralf Emmers, "Regional Hegemonies and the Exercise of Power in Southeast Asia: A Study of Indonesia and Vietnam," Asian Survey 45, 4 (2005): 661.

${ }^{10}$ A 2016 report by the Politics of Papua Project at the University of Warwick claimed that the Indonesian military engaged in violent operations in Papua and 100,000 people were directly killed between 1963 and 2005. The report also documented media coverage on security apparatus atrocity. "Assessment Report on the Conflict in the West Papua Region of Indonesia," Politics of Papua Project at the University of Warwick, April 2016, http://www2.warwick.ac.uk/fac/soc/pais/research/researchcentres/ierg/ westpapua/assessmentreport.pdf, accessed July 28, 2016. A report by Amnesty International also documents various past atrocities by the Indonesian military in Papua; see "Indonesia-Impunity and Human Rights Violations in Papua," Amnesty International Report, 2002, https://www.amnesty.org/ download/Documents/116000/asa210152002en.pdf, accessed May 14, 2015.

11 Matoa, or Pometia pinnata, is the name of local fruit that can be found in Papua.

${ }^{12}$ David P. Fidler, "Police in Counterinsurgency: The Challenge of Comprehensive Reformation," in Policing Insurgencies: Cops as Counterinsurgents, ed. C. Christine Fair and Sumit Ganguly (Oxford: Oxford University Press: 2014), 327.

13 The relative paucity of studies on policing in Indonesia, especially Papua, is understandable due to the difficulty in accessing the field. I am personally indebted to one of the reform-minded police officers who vouched for me, which opened up access to the field and enabled me to complete this research.
} 
primarily from the perspective of OPM and local inhabitants. Sufficient attention to examining how Jakarta approaches counterinsurgency under the present political context of democracy has been absent, as are analyses of the contemporary security forces' operational conduct. ${ }^{14}$ Although some studies have tried to analyze and explicate military conduct in Papua, ${ }^{15}$ no study has captured the current shift toward and leadership of the police in terms of counterinsurgency conduct. This inattention is perplexing because, in the current democratic environment, while the task of suppressing insurgents to some extent still falls under the national armed forces' purview, the hard work of restoring public order and winning the support of the aggrieved population is done largely by the domestic force.

Given the growing importance of policing in counterinsurgency, ${ }^{16}$ this study seeks to address critical empirical gaps in the literature by documenting the roles that forces have played in the contexts of the counterinsurgency campaign in Papua. This article describes a configurative ideographic study with the purpose of providing a detailed description of Indonesia's counterinsurgency conduct that might be used in subsequent theory-building studies. It will do so by examining a single example of Indonesia's counterinsurgency operations in one of the high-risk regions in Indonesia-the aforementioned Aman Matoa Operation in West Papua. This study deployed qualitative analyses, with data collected through a thorough review of secondary literature, state documents, and interviews with relevant security officials and others with positions in Papuan society. An analysis of Aman Matoa will be beneficial to understanding the changing aspects of counterinsurgency operations in the post-Reformasi era.

This article is organized into four major sections. First, I discuss the current anatomy of insurgency activities in West Papua. Second, I describe the jurisdictional shift from the military to the police. The third section covers the central government policy for improving political conditions in Papua, including its economic, diplomatic (dialogue to negotiate peace deals with various quarters in Papua), and security-

14 The East West Center has published several pieces on domestic politics and violence in Papua; see, for example: Bobby Anderson, "Papua's Insecurity: State Failure in the Indonesian Periphery," East-West Center Policy Studies 73 (2015): 1-74; and Rodd McGibbon, "Plural Society in Peril: Migration, Economic Change, and the Papua Conflict," East-West Center Policy Studies 13 (2004). See also Marcus Mietzner, "Local Elections and Autonomy in Papua and Aceh: Mitigating or Fueling Secessionism?" Indonesia 84 (October 2007). Past studies also focused on the ethnographic dimensions of local inhabitants and the organizational structure, the ideology, and the strategic planning of OPM. See, for example: Eben Kirksey, Freedom in Entangled Worlds: West Papua and the Architecture of Global Power (Durham: Duke University Press, 2012); Danilyn Rutherford, Laughing at Leviathan: Sovereignty and Audience in West Papua (Chicago: University of Chicago Press, 2012); Peter King, "Morning Star Rising? Indonesia Raya and the New Papuan Nationalism," Indonesia 73 (April 2002): 89-127; and Johannes R. G. Djopari, Pemberontakan Organisasi Papua Merdeka [Impact of the resistance of Free Papua Movement] (Jakarta: Gramedia Widiasarana Indonesia, 1993).

${ }^{15}$ For studies on the armed forces approach in Papua, see, for example: Bilveer Singh, Papua, Geopolitics and the Quest for Nationhood (New Brunswick: Transaction Publishers, 2008); and Matthew N. Davies, "TNI and Polri Forces in West Papua: Restructuring and Reasserting Sovereignty," Strategic and Defence Studies, 2006. Kilcullen also attempts to study Indonesian counterinsurgency, yet did not mention the role of police in his study. See David Kilcullen, "Globalisation and the Development of Indonesian Counterinsurgency Tactics," Small Wars and Insurgencies 17 (2006): 1, 50-52.

${ }^{16}$ See the discussion in C. Christine Fair and Sumit Ganguly, "The Police in Counterinsurgency Operation," in Policing Insurgencies: Cops as Counterinsurgents, ed. Christine Fair and Sumit Ganguly (Oxford: Oxford University Press, 2014), 1-18. 
building measures. The last part of this article deals with the interagency processes between the police and the military in conducting the Aman Matoa operation. My final analysis attempts to examine whether the Indonesian's law enforcement operation provides a better approach to counterinsurgency than that of the military.

\section{Terror and Nonviolence, Papuan Insurgency in the Eyes of Security Agencies}

The government of Indonesia defines the OPM as a separatist insurgency group. ${ }^{17}$ The movement emerged from augmented grievances caused by economic and resource exploitation, and human rights violations, during President Suharto's authoritarian government. ${ }^{18}$ Moreover, widespread disappointment in the inability of a postReformasi government to improve economic conditions for the masses and the failure to hold human right abusers accountable also contributed to OPM's viability. ${ }^{19}$ Therefore, the OPM insurgency can be defined as a struggle of non-ruling groups of Melanesian-ethnic Papuans that consciously uses political resources and violence to destroy the legitimacy of local government infrastructures that are set up by the Indonesian government. ${ }^{20}$

According to a 2015 report by the Papua Regional Police, the Free Papua Movement can be categorized into two main streams: Armed Criminal Groups (Kelompok Kriminal Bersenjata, KKB) and Political Criminal Groups (Kelompok

17 There are different perceptions with regard to whether the Free Papuan Movement is a resistance movement or an insurgency. The main difference between the two is that an insurgency does not involve resistance against foreign invasions, but only against the same nation in which they are located. Bard O'Neill, in his book Insurgency and Terrorism, defines insurgency as the struggle of a nonruling group that consciously uses political resources (e.g., organizational expertise, propaganda, and demonstration and violence) to destroy the basis of legitimacy of one or more aspects of politics. Despite much controversy, Papua is recognized by the United Nations as part of Indonesia's sovereignty, which provides legal grounds for the Indonesian government to argue that this movement is a separatist insurgent group. This interpretation is based on the New York Agreement, between Indonesia and the Netherlands, signed August 15, 1962, at the United Nations. It reads in part: "the Netherlands will transfer administration of the territory to a United Nations Temporary Executive Authority (UNTEA) established by and under the jurisdiction of the Secretary-General upon the arrival of the United Nations Administrator appointed ... The UNTEA will in turn transfer the administration to Indonesia ..." Hence. in 1969. after the Indonesian government conducted a referendum called "Act of Free Choice" (supposedly under UN supervision). Papua was internationallv recognized as a part of Indonesia. There are different opinions regardng the legitimacv of the referendum process. Nevertheless. the Indonesian government has asserted its sovereignty over Papua ever since, which qualifies OPM as an insurgency from Indonesia's perspective. See: "UN Agreement between the Republic of Indonesia and the Kingdom of the Netherlands Concerning West New Guinea (West Irian)," Free West Papua Campaign, https://www.freewestpapua.org/ documents/the-new-york-agreement/, accessed July 29, 2016; and Bard E. O'Neill, Insurgency and Terrorism: Inside Modem Revolutionary Warfare (Washington: Brassey's Inc, 1990), 13.

${ }^{18}$ King, “Morning Star Rising?” 96.

${ }^{19}$ Mietzner, “Local Elections and Autonomy in Papua and Aceh,” 3.

${ }^{20}$ Indeed, to really understand the aspirations of Papuans would require a systematic survey, but accomplishing that is not feasible for various reasons, including the politically sensitive nature of such an undertaking. However, based on discussions with people from various segments of society, including several village chiefs, prominent religious figures, and inhabitants of Jayapura and Sorong, it can be seen that they have different ideas about what independence means and what achieving it entails. All Papuans want freedom, but many are unsure whether it requires separating themselves from Indonesia's sovereignty. Most agree on two things: first, Papua should have benefited from more economic and social development by now, considering its rich natural resources; and any move toward independence must reflect the importance of respecting local custom and tradition. 
Kriminal Politik, KKP). Generally, the KKB and KKP use different strategies to upset the status quo. KKBs use terror and violence as their main method of action to compromise any sense of public safety. By contrast, as discussed below, KKPs use public demonstrations, press and media releases, and preaching through church networks to educate and influence the masses as well as foreign powers.

To identify the locals who are likely to become member or supporter of the OPM, the police often use the terms Orang Gunung (highlanders) and Orang Laut (coastal people). This profiling is based on domicile and disregards the fact that there are diverse tribes and clans living in the mountainous regions in Papua. Orang Gunung as a group has been identified as those individuals most likely to wage OPM's battles against Indonesia. The Orang Gunung has been OPM's main funding source, too, by providing proceeds from its criminal activities. Other supporters are the Orang Laut, or coastal people, who sometimes provide nonviolent material assistance. ${ }^{21}$ Those considered Orang Laut live in areas such as Sorong, Manokwari, Jayapura, and Merauke, which have relatively well-developed economic bases compared to the highlands. Orang Laut areas comprise a mixture of locals and transmigrants from Sulawesi, Java, and Nusa Tenggara Barat. ${ }^{22}$ The Orang Gunung comprises mostly native inhabitants who live in mountainous areas and are scattered all over the region, such as at Paniai, Wamena, and Puncak Jaya. According to the Papua Regional Police's director of intelligence and security, the distinguishing feature of Orang Gunung (aside from their geographical distribution) is their darker black skin relative to the predominantly lighter black skin of Orang Laut. ${ }^{23}$ Although it is doubtful that Orang Gunung and Orang Laut share a united vision for independence, thus far they have been able to work together to consolidate whatever power their different advantages afford them.

The large footprint of Papua's security apparatus-combined with KKBs' internal squabbles-caused the KKBs to fragment, scatter, and organize into smaller groups. According to the 2015 Threat Perception Report by Directorate of Intelligence and Security of the Papua Regional Police, there are seven large groups recognized as being $\mathrm{KKB}$ and each has a leader who declared himself to be commander-in-chief of TPN/OPM. ${ }^{24}$ Each group supports and cooperates with several other groups to accomplish their activities. For example, the large Goliath Tabuni group, based in Tingginambut region, Puncak Jaya regency, controls the activities of other groups such

${ }^{21}$ Interview with the Papua Regional Police's director of intelligence and security, at the police headquarters, Jayapura, April 7, 2015.

22 Ibid. Several authors have also discussed the dichotomy of Highlander and Coastal Papuans, although not specifically related to security issues. See: Mietzner, "Local Elections and Autonomy in Papua and Aceh," 11-12; and McGibbon, "Plural Society in Peril."

${ }^{23}$ When discussing Papuans' physical and cultural attributes with security officers, I sensed that they held patronizing views that were reinforced by the security apparatus. Notwithstanding security personnels' various attempts to better comprehend and expose themselves to local culture, ethnocentric preconceptions persist. For example, the police regularly use the term muka sama kaki lebar, or musakaleb, to describe Orang Gunung (highlanders) associated with the OPM. That derogatory term can be translated as referring to any individual with undistinguishable facial features and large feet. The casual and frequent use of that term also highlights security officers' inability to discriminate between combatants and townspeople, as officials see all people as having similar faces. This assessment is based on several interviews I conducted with police officers at the Regional Police Headquarters, Jayapura, April 7, 2015. ${ }^{24}$ Dirintelkam Polda Papua, Hakekat Ancaman KKB dan KKP di Papua Tahun 2015, 20-40. 
as Leo Magay Yogi in Paniai, Ayub Waker in Tembagapura, and Theny Kwalik in Timika. The large Hans Uri Joweny group, concentrated in Demta region, Jayapura, has several groups under its influence, with bases in Sorong, Mamberamo, Tabi, Yapen, Waropen, and Lapago. Since 2011, Hans Uri Joweny group and associates have also been expanding and recruiting more personnel and planning actions in Wamena, Timika, Paniai, Merauke, Manokwari, and Nabire. Matthias Wenda, who declared himself as the commander-in-chief of the West Papua Liberation Army (Tentara Revolusi West Papua, TRWP), also has a vast network spreading all over Papua, especially around the Jayapura area and along the border of Indonesia and Papua New Guinea.

KKBs' direct actions vary with their specific goals: to strengthen their domestic constituencies; to delegitimize local governments by degrading citizens' sense of public safety; and to publicize their existence and potential to domestic and international audiences. Interfering with any sense of domestic security through the use of violence, along with weakening Indonesia's government's credibility, are vital KKB goals, and have been attempted by shooting and killing Indonesian military and personnel, staging street demonstrations, and organizing many other acts. According to a Papua Regional Police report, between 2013 and 2014 there were sixty-seven instances of armed violence in various areas of Papua province alone. The violence is usually conducted during or around the time of several important dates for the KKB, such as: November 19, which commemorates the founding of the National Committee of West Papua (Komite Nasional Papua Barat, KNPB); December 1, the anniversary of West Papua; and December 14, Melanesian Day. Around the time of any of those important days, giat teror, or violent action, could be waged to obliterate any sense of domestic security as a way to decrease the local government's legitimacy and effectiveness. ${ }^{25}$

There have also been an increasing number of attacks on the security apparatus. On September 25, 2014, Prada Abraham Rumadas, an infantry member of Yonif 751 $\mathrm{R}$, was shot dead at Koga market, Ilaga district, and his SS1-V1 assault rifle went missing. ${ }^{26}$ On December 3, 2014, Aipda Thomson Siahaan and Bripda Apriyanto Forchen, personnel of the Papua Regional Police, encountered a similar fate. ${ }^{27}$ They were shot dead on their truck while delivering chairs to one of the churches in Ilaga District. Two of their AK 47s went missing. On January 1, 2015, two Brigadier Mobile personnel and a Freeport-McMoRan, Inc., security officer were murdered in Mimika and their guns were stolen. According to the police's 2014 Threat Perception Report, throughout 2014-15, there were at least fourteen attacks on security personnel in the Papua region with the goal of taking the victims' weapons. ${ }^{28}$

${ }^{25}$ Polda Papua [Papua Regional Police], Rencana Operasi Aman Matoa V-2014 [Aman Matoa V Operation Plan 2014] (Jayapura: Polda Papua, 2014), 3.

${ }^{26}$ Alfian Kartono, "Peti Jenazah Prada Abraham Disambut Isak Tangis" [The body of Prada Ambraham was welcomed with tears], Kompas, September 26, 2014, http://regional.kompas.com/read/2014/09/26/ 16520721/Peti.Jenazah.Prada.Abraham.Disambut.Isak.Tangis, accessed May 14, 2015.

${ }_{27}$ Alfian Kartono, "Dua Jenazah Anggota Brimob Korban Penembakan di Ilaga Diterbangkan ke Jayapura" [Two Brimob corpses were sent to Jayapura], Kompas, December 4, 2014, http://regional.kompas.com/read/ 2014/12/04/13513701/Dua.Jenazah.Anggota.Brimob.Korban.Penembakan.di.Ilaga.Diterbangkan.ke. Jayapura, accessed May 14, 2015.

${ }^{28}$ Dirintelkam Polda Papua, Hakekat Ancaman KKB dan KKP di Papua Tahun 2015, 5-15. 
Most of the KKBs' weapons were obtained during hostile raids on security forces. ${ }^{29}$ For instance, Goliath Tabuni, one of the biggest groups, possesses thirteen weapons, including M16s and AK 47s, which were acquired by looting security apparatuses' arsenals. Some of their weapons were also acquired from other conflict areas, such as Ambon; and from illegal arms traffic from overseas, especially from Papua New Guinea, the Philippines, and Australia. ${ }^{30}$ Other KKBs, such as Ayub Waker and Purom Wenda, have seventeen and eleven weapons, respectively, that were stolen from the security apparatus. ${ }^{31}$ These trends are worrying as they highlight the rise of violence in the region and the weakness of security personnel in the face of insurgents.

The most common sources of money are fundraising through local churches, and waging criminal activities, such as extortion, theft, looting, and illegal gold-panning. One common KKB strategy is to extort special autonomy funds that are distributed by the state to local district governments to develop villages. ${ }^{32}$ Extorting money from contractors doing business with the state has also been a common practice. ${ }^{33}$ Illegal gold-panning is also engaged in by various groups, such as Goliath Tabuni in the Puncak Jaya area, Leo Magay in Paniai, and Militer Murib in Ilaga.

On the nonviolent front, several groups of Papuan residents have actively rallied political support from domestic as well as international audiences. As fragmented as the $\mathrm{KKB}$, what government officials call the "KKP" consists of several different groups. There are at least five primary KKPs that are actively waging a political struggle against the Indonesian government: Federal Republic of West Papua (Negara Republik Federal Papua Barat, NRFPB), West Papua National Coalition for Liberation (WPNCL), West Papua Interest Association (WPIA), International Lawyers for West Papua (ILWP), and the KNPB. They are not necessarily in harmony with one another, a trait they share with most groups competing to gain influence in Jayapura. They cooperate with smaller political groups and sometimes compete with one another to gain supporters. ${ }^{34}$ For example, NRFPB is at odds with KNPB, as the group accused KNPB of failing to respect principles of nonviolence - such as by perpetrating a violent protest. NRFPB also denounced its affiliation with the United Liberation Movement for West Papua (ULMWP) due to different political goals and means to achieve the goals. ${ }^{35}$

KKPs' main objectives are to rally political support from domestic as well as international sources, and to delegitimize the current government by creating instability. According to the Papua regional Police, between 2013 and 2014 three common nonviolent activities used by KKPs to foment domestic disruption were

29 Ibid., 20-40.

30 Ibid., 20-21.

31 Ibid., 25-27.

32 Interview with Papua director of intelligence and security, April 7, 2015.

${ }^{33}$ Dirintelkam Polda Papua, Hakekat Ancaman KKB dan KKP di Papua Tahun 2015, 24-25.

${ }^{34}$ Idid., 51-61

${ }^{35}$ See: Markus, "Demo KNPB Bertentangan Dengan Kultur Toleransi Papua" [NRFPB claimed that protest perpetrated by KNPB was against Papua culture of tolerance], Papua News, June 10, 2016, http:// papuanews.id/2016/06/10/demo-knpb-bertentangan-dengan-kultur-toleransi-papua/, accessed October 25, 2016; and Alfred Karafir, "Terpecah Belah, NRFPB Tak Dukung ULMWP dan KNPB" [NRFBP denounced support toward ULMWP and KNPB], Papua News, July 28, 2016, http://papuanews.id/ 2016/07/28/ terpecah-belah-nrfpb-tak-dukung-ulmwp-dan-knpb/, accessed October 25, 2016. 
demonstrations, press and media releases, and outreach and education through church networks. ${ }^{36}$ On the international front, the focus has been varied, from promoting the issues through international organizations, such as the United Nations (UN), to enlisting the support of state actors and nonstate actors (e.g., politicians from various countries, human-rights activists, and international lawyers). The countries of choice are members of the Melanesian Spearhead Group (MSG), such as Papua New Guinea and Fiji. ${ }^{37}$ An international milestone was a summit in London, May 3, 2016, attended by members of parliaments from the wider Pacific and European Union, as well as Liberation Movement leaders such as Benny Wenda, which produced a declaration calling for an internationally supervised vote on independence in West Papua. ${ }^{38}$

The abovementioned explanations have highlighted that, from the perspective of the anatomy of insurgency, the OPM has been able to advance progressively by creating an infrastructure that mirrors the state's governing structure. ${ }^{39}$ Although the OPM has not been able to build a centralized organization, it has created sanctuaries and training centers in remote regions. Through the activities of KKBs and KKPs normal state security and operations have been disrupted and the OPM has gained international support.

The insurgency's use of nonviolent activities makes it difficult for counterinsurgents effectively to curb the movement. While the police can respond to insurgents' violent actions, nonviolent activities such as peaceful protests and unionorganizing are considered legitimate rights under a democracy. ${ }^{40}$ Moreover, the democratic landscape also creates asymmetric situations, where the force is expected to abide by the rules of law, while insurgents often choose to break the law as a way of gaining an advantage over and disrupting the security apparatus. The blurring line between insurgents and local populations can also be an impediment for the police, who must discriminate between the two. In at least one instance, the resulting frustration resulted in a draconian response. In early May 2016, images of hundreds of

36 Idid., 51.

${ }^{37}$ Idid., 42-44. The MSG is an intergovernmental organization comprising Fiji, Papua New Guinea, the Solomon Islands and Vanuatu, and the Kanak and Socialist National Liberation Front of New Caledonia. Indonesia has been an associate member since 2015.

${ }^{38}$ Helen Davidson, "West Papua: UN Must Supervise Vote on Independence, Says Coalition," The Guardian, May 3, 2016, https://www.theguardian.com/world/2016/may/03/west-papua-un-mustsupervise-vote-on-independence-says-coalition, accessed August 4, 2016.

${ }^{39}$ For example, the OPM has adopted a national flag and anthem, national emblem, national currency, and a governance structure comprising executive, legislative, and judicial branches. Dirintelkam Polda Papua, Hakekat Ancaman KKB dan KKP di Papua Tahun 2015, 56-60.

40 These rights are protected under the 1945 Constitution of the Republic of Indonesia, specifically under Article 28 on human rights: "The freedom to associate and to assemble, to express written and oral opinions, etc., shall be regulated by law." As in Indonesia, the constitution is Lex Superior, or the fundamental and highest law. Any legislative, executive, or administrative act that contravenes the provision of the constitution shall be annulled and the Constitutional Court will invalidate them as unconstitutional. Although in Indonesia the constitution can be revised at will, and it has gone through four series of amendments, any proposed revision has to undergo a long process of deliberation. As such, any proposals for change are unlikely to go against the basic principles of freedom stipulated at the Preamble to the Constitution. Moreover, Indonesia today is a vibrant democracy, and any attempts to curb freedom of expression will face major resistance from various quarters of society. See. "The 1945 Constitution of the Republic of Indonesia," http://www.ilo.org/wcmsp5/groups/public/_--ed protect/_protrav/---ilo_aids/documents/legaldocument/wcms_174556.pdf, accessed October 25, 2016. 
Papuans being held at police headquarters caught international media attention. ${ }^{41}$ It was reported that as many as 1,700 individuals had been rounded up or arrested, although the vast majority of those detained have since been released. ${ }^{42}$ This kind of heavy-handed response is used effectively by the OPM to feed its antigovernment narrative. Innocent victims of such abuse of power may thereafter decry the deterioration of public safety, while detained insurgents can be used for media and international propaganda.

Discerning the truth about actual events in Papua is difficult. ${ }^{43}$ The OPM chooses to highlight events that create negative perceptions with regard to security issues, while the Indonesian government promotes a narrative of positive change. This dichotomy highlights another dimension of struggle in Papua: aside from the physical battles waged between the insurgents and counterinsurgents, a war of narratives is ongoing. Both are fighting for legitimacy in the eyes of locals as well as international audiences.

\section{Protecting Indonesia's National Security: TNI and POLRI, TNI vs. POLRI}

As the insurgent movement continues to exploit narratives of security personnel weakness and dysfunction that feed antigovernment sentiments, the reconstruction of the idea of "counterinsurgent" in the mind of the general population becomes important. This is to strengthen the legitimacy of the government's hold on political power as part of the narrative war against insurgents. Indonesia's counterinsurgency approach is an attempt to position the police as the spearhead against insurgents, instead of the military, which traditionally held such responsibilities. The underlying assumption is that the police force, as an institution, is accountable to the people through adherence to the rule of law. This is particularly crucial in Indonesia's democratic context, where civilians have been unable to subordinate the military to the civilian government. ${ }^{44}$ The police, despite suffering from problems related to systemic powerlessness and corruption, symbolize democratic reform. Empowering

${ }^{41}$ Johnny Blades, "International Surge on West Papua amid Mass Demos," Radio New Zealand, May 9, 2016, http://www.radionz.co.nz/international/pacific-news/303417/international-surge-on-west-papua-amidmass-demos, accessed July 28, 2016.

42 "Most West Papua Detainees Released," Radio New Zealand, May 4, 2016, http://www.radionz.co.nz/ international/pacific-news/303049/most-west-papua-detainees-released, accessed July 28, 2016.

43 To portray accurately the current situation, the free access of media, nongovernmental organizations, foreign academics, and foreign observers in West Papua is imperative. This is important not only to clarify various reports' discrepancies, but to ensure that a valid and transparent narrative is available. Rigorous academic research on the current situation in West Papua is also an important pathway to a resolution of the conflict.

${ }^{44}$ Various scholars agreed that separating the POLRI from TNI was an essential element of reform. This thinking is reflected in the drafts of policy briefings prepared by various Indonesian scholars for consideration by the People's Consultative Assembly (MPR) at the 1999 General Session. See "The Civil Supremacy Paradigm, a Blueprint for Reforming the Position and Role of the Military on the Road to Democracy in Indonesia," National Democratic Institute, https://www.ndi.org/files/433_id_civsupr.pdf, accessed August 10, 2016. Sebastian and Gindarsah also noted that multiple efforts to establish layers of civilian control and supremacy over the military are not without loopholes. For further details on the shortcomings of the regulatory framework of security sector reform, see Leonard Sebastian and lis Gindarsah, "Taking Stock of Military Reform in Indonesia," in The Politics of Military Reform: Experiences from Indonesia and Nigeria, ed. Jurgen Ruland, Maria-Gabriela Manea, and Hans Born (Heidelberg: Springer, 2013), 38-41. 
the police to fight insurgents at the expense of the military is a conscious effort to instill the idea of democracy and human rights in the counterinsurgency agenda, thereby, it is hoped, shoring up the Indonesian national government's legitimacy.

\section{A Shift from TNI to POLRI}

In 2000, the Indonesian government detached the Indonesian police from the Indonesian military. ${ }^{45}$ The separation is important in two senses. First, it gives a sense of civilian supremacy in maintaining national security by adopting a law enforcement framework that is in accord with the democratic principles enshrined in the constitution. Second, it allows the military to embark on modernizing and professionalizing its forces to focus exclusively on defense against an external enemy. As a consequence of this POLRI-TNI realignment, counterinsurgency was shifted to the domain of the police. ${ }^{46}$ Under current law, the Indonesian government acknowledged insurgents' status as Indonesian citizens who enjoyed certain rights, including fair treatment and due process under the law. ${ }^{47}$ This is different from past approaches that regarded insurgents as combatants (versus citizens), which justified extrajudicial measures such as torture or even killing when necessary. Under the new approach, the police can only capture insurgents once there is sufficient evidence of wrongdoing according to Indonesian law. ${ }^{48}$

From 1950 up to the early 2000s, the Indonesian government relied primarily on its army territorial structures to maintain domestic stability. Each structure, called a "military area command" (Komando Daerah Militer, Kodam), allows military forces to embed themselves in the social fabric of the local population and wield influence at the village level. The military's influence is thus dispersed throughout Indonesia, from the national down to village levels. This structure allows military personnel to gain human intelligence, conduct terrain analysis, and conduct guerrilla-type operations

45 TAP MPR No. VI/MPR/2000, on the separation of POLRI and TNI, was issued during Abdurahman Wahid's presidency in an effort to establish civil supremacy. This law defines and explains the division of functions between the two, and TAP MPR No. VII/MPR/2000 further elaborates on the separation of powers. In general, the law specifies that TNI is the state tool for ensuring the unity of Indonesia, while POLRI is responsible for protecting domestic security and order, enforcing the law, and providing service to the citizenry. See: "Ketetapan MPR RI No. VI/MPR/2000 tahun 2000 Tentang Pemisahan Tentara Nasional dan Kepolisian Republik Indonesia" [Decision of the People's Consultative Assembly of the Republic of Indonesia No. VI/MPR/2000 year of 2000 on the separation of POLRI and TNI], Hukum Online, http://www.hukumonline.com/pusatdata/detail/1t4ffe8d256bfoo/node/657/tap-mpr-novi_mpr_2000-tahun-2000-pemisahan-tentara-nasional-indonesia-dan-kepolisian-negara-republikindonesia, accessed August 10, 2016.

46 The police's primacy in maintaining internal security was further cemented by the law of UU No. 2/2002 on the Police Force of the Republic of Indonesia and the provision of Chief of Police No. 9/2011 on the Indonesian Police Force. See "UU no. 2/2002 tentang Kepolisian Republik Indonesia" [Law on the Indonesian police force], https://portal.mahkamahkonstitusi.go.id/eLaw/mg58ufsc89hrsg/uu22002.pdf, accessed October 24, 2016; see also "Peraturan Kepala Kepolisian Negara Republik Indonesia No. 9/2011 tentang Manajemen Operasi Kepolisian" [Provision of chief of police no. 9/2011 on police force operation management], https://bagopspolrestsm.files.wordpress.com/2015/05/perkap-nomor-9-tahun-2011-ttgmanajemen-ops-kepolisian.pdf, accessed 24, October 24, 2016.

${ }^{47}$ Interview with the Papua Regional Police's chief of operation bureau, at the police headquarters, Jayapura, April 7, 2015.

48 Ibid. 
against insurgents. ${ }^{49}$ The creation of a territorial structure was inspired by the success of a similar structure during the struggle against the Netherlands after independence from 1945-49.50 The emergence of many internal conflicts, after Indonesia gained international recognition over its territory in 1949, influenced the state's decision to keep the territorial structure and to accelerate the creation of an overarching territorial command system to control domestic instability. ${ }^{51}$ After 1949 , the army strategic doctrine of territorial warfare, which was initially directed to protect Indonesia against the threat of colonial power, was reoriented to protect Jakarta's political establishment against growing internal threats in various regions by prioritizing the army's role in counterinsurgency.

During the Suharto period, starting from the year of 1967, with the military doctrine of Catur Dharma Eka Karma (National Defense and Security) effectively enacted, the territorial command system was also used to demonstrate and impose authoritarian disciplinary power - an important tool for preventing and combating social unrest. ${ }^{52}$ Yet such a domestic-focused army structure is deemed incompatible with the ideals of a professional military. ${ }^{53}$ The abuse of power is evident from the counterinsurgency tactics encouraged by such a structure, such as the "fence of legs" (pagar betis) strategy, which allows the regional military to play a dominant role in matters of state and society at the expense of individuals' rights and freedom. ${ }^{54}$ The overarching territorial structure also allowed Indonesian Special Forces (Komando Pasukan Khusus, Kopassus) to wage covert warfare against insurgents. ${ }^{55}$ While Kopassus performs mentoring roles and de facto field leadership over an expanded base

${ }^{49}$ Pusat Sejarah dan Tradisi TNI [Center for History and Tradition of the TNI], Sejarah TNI 1960-1965 [TNI history 1960-65] (Jakarta: TNI Headquarters and the Center for History and Tradition of the TNI, 2000), 64.

${ }^{50}$ Nugroho Notosusanto, The National Struggle and the Armed Forces in Indonesia, fourth edition (Jakarta: Centre for Armed Forces History, 1994), 26-28.

${ }^{51}$ Internal conflicts involving many parts of the country emerged, such as the operation against the Indonesian Communist Party (PKI) in Madiun, as well as numerous secessionist movements, such as Papua's OPM, the Free Aceh Movement, and Republik Maluku Selatan (RMS) in the Moluccas. See Pusat Sejarah dan Tradisi TNI, Sejarah TNI 1950-1959, 81-128.

52. The counterinsurgency frameworks were stipulated with several goals: create internal stability by establishing strong disciplinary forces, build resilience by engineering Indonesian nationalism, and oversee the abolishment of insurgent organizations from their centers down to the regional level. The latter goal refers to the dissolution of the Indonesian Communist Party (Partai Komunis Indonesia, PKI). On November 12, 1965, through the President's Provision No. 162/Koti/1965, territorial structures were expanded to seven military district commands responsible for internal security (Komando Operasi Pemulihan Keamanan dan Ketertiban, Kopkamtib). Pusat Sejarah dan Tradisi TNI, Sejarah TNI 19501959), 81-128.

${ }^{53}$ In democratic countries, military deployment in an internal security role is deemed incompatible with the ideal of a professional military force that is apolitical, places its concern exclusively on strategic matters, and leaves political decisions to civilian authorities. See Samuel P. Huntington, The Soldier and the State: The Theory and Politics of Civil-Military Relations (Cambridge: Harvard University Press, 1957), 84.

54 'The pagar betis, or "fence of leg" tactic, employs local militias and auxiliaries for static security duties and intelligence work. To build such a network of intelligence, the army personnel engaged in community service and civic improvements to win over the population's support. As noted by Kilcullen, pagar betis was used in almost every operation in Indonesia, whether a conflict or for conflict prevention. Kilcullen, "Globalisation and the Development of Indonesian Counterinsurgency Tactics," 50-52.

${ }^{55}$ Kopassus is an elite branch of the Indonesian army comprising groups of soldiers that are trained for special-operations missions for the Indonesian government, such as intelligence gathering, sabotage, and counterinsurgency. 
of line infantry, individual Kodams provided the means for infiltration to various areas through trained volunteer militia cadres as proxies. ${ }^{56}$

After the fall of the New Order in 1998 and the apparent acceleration toward democratic ideals under Habibie, the army's territorial structure came under scrutiny, as it was seen as the central government's primary tool of domestic control. Reform was advocated by individuals within the army and by scholars who sought to dismantle the territorial system; they urged the Indonesian military to shift its focus to external threats. ${ }^{57}$ Under this scenario, the territorial structure would be abolished and the army's local authority would be transferred to the local government. Several middle ways were also proposed, such as a gradual abolition of the commands. ${ }^{58}$ However, the final decision was to enlarge and strengthen the territorial structure. ${ }^{59}$ This decision was justified by the argument that the territorial system is an indivisible foundation that cements the unity of Indonesia as a state. The deficiencies of the Indonesian police's capacity to ensure internal security also became a major consideration for keeping the territorial command. ${ }^{60}$ Nowadays, a decentralized defense and territorial structure manifested under a Kodam are still the backbone of Indonesia's defense. ${ }^{61}$

While the Indonesian military has considerably withdrawn from the political scene, and some military leaders have endorsed the police as the proper spearhead for

\footnotetext{
${ }^{56}$ Damien Kingsbury, Power Politics and the Indonesian Military (London: RoutledgeCurzon, 2003) 99-101.

57 The opposition to territorial structure arose primarily from pro-reform, pro-democracy, and proprofessional military elements. For further details, see Kusnanto Anggoro, "Organisasi dan Postur Pertahanan Indonesia Masa Depan" [The future of Indonesian defense organization and posture], in Likuidasi Komando Teritorial dan Pertahanan Nasional [Liquidation of territorial command and national defence], ed. M. Riefqi Muna (Jakarta: Center for Alternative Defence \& Security Studies, 2002), 71-83.

${ }^{58}$ See: Awaloeddin Djamin, "TNI dan Refomasi: Tanggapan Atas RUU TNI" [TNI and Reformasi: A response to the draft of the law on the Indonesian Armed Forces], in Menuju TNI Prefesional Tidak Berbisnis dan Tidak Berpolitik-Perjalanan Advokasi RUU TNI [Achieving professional TNI-A journey to scrutinize the draft of the law on the Indonesian Armed Forces], ed. Rusdi Marpaung et al. (Jakarta: Imparsial, 2005), 86; and Agus Widjojo, "Komando Teritorial dalam Reformasi Sektor Pertahanan" [Territorial command in security sector reform], in Almanak Reformasi Sektor Keamanan Indonesia 2007 [Almanac of security sector reforms 2007], ed. Beni Sukadis (Jakarta: Lembaga Studi Pertahanandan Studi Strategis Indonesia [Institute of Defence and Strategic Studies] and Geneva Centre for the Democratic Control of Armed Forces, 2007), 141.

59 In 2002, during an interview with Kompas magazine, Army Chief of Staff Ryacudu reaffirmed the position that the territorial structure is pivotal. Susilo Bambang Yudhono, acting as president, stressed the same position. Joko Widodo, as Indonesia's seventh president, also stated the point that territorial structure is important to protect Indonesia's territorial integrity. See: "SBY Tolak Penghapusan Komando Teritorial TNI" [Yudhoyono turned down the movement to dismantle territorial command], Tempo, August 1, 2004, https://nasional.tempo.co/read/news/2004/08/01/05545804/sby-tolak-penghapusankomando-teritorial-tni, accessed August 16, 2016; and "Jokowi Bantah Akan Bubarkan Koramil hingga Kodim" [Jokowi denies that he will dismantle Koramil and Kodim], Kompas, June 27, 2016. http:// nasional.kompas.com/read/2016/06/27/20501981/jokowi.bantah.akan.bubarkan.koramil.hingga.kodim, accessed August 16, 2016.

${ }^{60}$ See Kompas interview series, "Pernyataan Mantan Panglima TNI Jenderal TNI (Pur) Endriartono Sutarto" [Statement of former commander in chief of the Indonesian military General (ret.) Endriarto Sutarto], Kompas, July 29, 2004.

${ }^{61}$ In terms of size, two thirds of the army's power is concentrated in the regional forces manifested in thirteen Kodams that are dispersed throughout Indonesia. See International Institute for Strategic Studies (IISS), The Military Balance 2015 (London: IISS, 2015), 253-56.
} 
creating internal stability, the army has not fully withdraw from the domestic scene. ${ }^{62}$ That is primarily because of the army's longstanding involvement in internal security operations and lack of confidence in the ability of the police to create and maintain order, especially in a conflict prone and strategic area such as Papua. By issuing law UU 34/2004 on the Indonesian military, the government of Indonesia provided a window of opportunity for the military to continue to play strong roles in regional conflicts. ${ }^{63}$ This law has indicated the unwillingness of the Indonesian military to move on from its role as the national security guarantor, including fighting insurgents, whose activities now, supposedly, should fall under jurisdiction.

\section{Tension and Cooperation between TNI and POLRI in Papua}

National security is supposed to fall under the police's jurisdiction, but the army is unwilling to dismantle its domestic territorial structure. This has created an interesting dynamic, as both entities have developed similar territorial commands that overlap in terms of function and jurisdiction. ${ }^{64}$ The overlapping structures provide a venue for the regional military, local, police, and civilian authorities to interact with one another. With the trend in Papua of pemekaran daerah, or proliferation of new regencies and municipalities, the focus of both the police force and army is to add new administrative areas by expanding their own organizational structures in accordance with new civilian structures.

The police force in Papua, in terms of its structure, is well-entrenched at the local level relative to the regional military. While the military has only one Kodam in the Papua region, the police manage two regional headquarters: one in Jayapura and Manokwari. The overall ratio of regional personnel to local inhabitants is about 1:300 (1:383 in Papua province and 1:215 in West Papua province). The Papua Regional Police also manage 22 command branches (polres), 125 sector branches (polsek), and 41 subsectors, with more than eleven thousand total personnel. In West Papua, the police have 9 command branches, 51 sector branches, and 3 subsectors with more than thirty-five hundred personnel. In the future, the overarching structure is expected to expand, so that each village will have its own "disciplinary forces" unit,

62 "TNI Continues to Press for Expanded Role in Internal Security," Tempo, March 11, 2016, http://en. tempo.co/read/news/2016/03/11/055752655/TNI-Continues-to-Press-for-Expanded-Role-in-InternalSecurity, accessed August 16, 2016.

${ }^{63}$ Despite the withdrawal of the military from politics, the law on the Indonesian military-UU $34 / 2004$ - nevertheless provided a foundation from which the flexible Indonesian military could play limited roles in civilian affairs. For example, Article 47, paragraph 2 of UU TNI 34/2004 stipulates that TNI may hold several political positions. The law also does not clearly delineate the oversight of military operations other than during war (MOOTW). That shortcoming has been used as justification to expand the army's role in internal security issues-including to combat armed separatists, fight suspected terrorists, and support the State Police in various activities to secure national security and public order. See "Undang-Undang Republic Indonesia No. 34 tahun 2004 tentang Tentara National Indonesia" [Law on the Indonesian military], TNI, March 5, 2015, http://www.tni.mil.id/files/UUTNI_No34.pdf, accessed August 16, 2016.

${ }^{64}$ For a discussion of the structural overlap between the police and military, see Davies, "TNI and POLRI Forces in West Papua," 15. 
adding sixty-five hundred personnel to Papua province alone, with 40 percent of new hires being from the village populations. ${ }^{65}$

Despite the preeminence of forces in leading counterinsurgency operations, the Indonesian army still plays an important role in West Papua. The current ratio of Indonesian army personnel to local inhabitants in Papua is $1: 168$, which makes Papua a relatively militarized region. ${ }^{66}$ In Papua, the army territorial structure was first created in 1950, primarily as the main tool to wage guerrilla-type operations against the growing presence of the Dutch. ${ }^{67}$ The highest military command there is Kodam XVII/Cendrawasih, located in Jayapura. In 1986, as part of the reorganization of the army, several Kodams, including the one in Papua, were dissolved and merged into Kodam XV/Pattimura, in Ambon, Maluku. This action was deemed counterproductive by the Indonesian army, as it triggered an escalation of separatist movements on the ground. A Kodam was reeestablished in Papua in 1999. With Kodams' proven success against the supremacy of the Netherlands in the early 1950s and their effectiveness for domestic civilian control, the central government and army used to perceive the Kodams as the primary tool to maintain sovereignty and keep the peace.

Moreover, after the central government decided to withdraw Kopassus from Papua, some of its duties, primarily intelligence-gathering responsibilities, were transferred to the Intelligence Detachment unit of Papua's Kodam. ${ }^{68}$ That transfer of such a key role positioned Kodam, in the eyes of the Indonesian military, as vitally important with regard to counterinsurgency in Papua. To fulfill such a role, Kodam XVII/Cendrawasih expanded its territorial and combat units to perform civic missions, and expanded its network of human intelligence. Also, the lowest type of territorial unit, called a Village Guidance Noncommissioned Officer (Bintara Pembina Desa, Babinsa), has been growing in number to carry out surveillance functions that once belonged to the Kopassus. ${ }^{69}$

Given the significant cuts in the military's authority coupled with the expansion of the police's role, and with the police and military sometimes sharing overlapping responsibilities, both institutions sometimes found themselves in opposition to one

${ }^{65}$ Polda Papua [Papua Regional Police], Laporan Kesatuan Tentang Situasi Kamtibmas Polda Papua [Unit report on the security in Papua] (Jayapura: Polda Papua, 2015).

${ }_{66}^{6}$ This claim is inferred by comparing Papua's ratio to Indonesia's national average, which is one soldier to 558 people. "West Papua Report December 2014," East Timor and Indonesia Action Network (ETAN), http://www.etan.org/issues/wpapua/2014/1412wpap.htm, accessed August 17, 2016.

${ }^{67}$ Pusat Sedjarah ABRI [Center of History of the Indonesian Armed Forces], Sejarah Angkatan Darat-Seri Textbook Sedjarah HANKAM/ABRI [History of the Indonesian army] (Jakarta: Dinas Sejarah HANKAM ABRI [Department of History of Defense and Security of the Indonesian Armed Forces], 1968), 114-16. 68 "Kopassus Ditarik dari Papua" [Kopassus withdrawn from Papua], Sinar Harapan, February 25, 2003. Although there are several allegations that Kopassus is still doing covert operations, the head of the Indonesian military's information center has denied such allegations. See "Kapuspen TNI: Tak Ada Kopassus di Papua" [Head of information center of the Indonesian military: There is no Kopassus in Papua], Intelijen, January 16, 2012, https://www.intelijen.co.id/kapuspen-tni-tak-ada-kopassus-di-papua/, accessed May 14, 2015.

${ }^{69}$ Babinsas play an important role in developing human intelligence sources, as well as for combat roles. Leonard C. Sebastian and Emirza Adi Syailendra, "Can Jokowi Bring Peace to West Papua?" The Diplomat, June 12, 2015, http://thediplomat.com/2015/06/jokowis-challenges-in-negotiating-peace-in-papua/, accessed May 14, 2015. 
another. In Papua, feuds between army personnel and the police are common. ${ }^{70}$ For example, on October 13, 2014, army and police personnel engaged in an armed clash in district Pirime of Lanny Jaya, Papua. ${ }^{71}$ Such altercations show the competitive nature of both state institutions, stemming from the Indonesian army's ongoing perception of itself as a superior institution due to its role during the state's struggles for independence and an unwillingness to focus exclusively on external defense. Nonetheless, the two institutions have tried to reconcile their differences, such as by conducting a combined exercise in November $2014 .^{72}$ On the one hand, despite the shift in responsibilities, POLRI needs the army's strong capacity on waging guerrillatype operations against insurgents in forest and mountain areas. For that purpose the army's well-entrenched structure is invaluable, and its Babinsas facilitate gathering valuable human intelligence..$^{73}$ On the other hand, the army relies on POLRI to keep military personnel involved in counterinsurgency operations, as the law has transferred such responsibility to the police. Although there's evidence that the army performed counterinsurgency operations on its own after the changeover, the actions were limited to evidence-gathering. For example, in a unilateral operation, the military seized homemade firearms on June $7,2014 .{ }^{74}$ The army still needs to coordinate with the police to prosecute those responsible for the illegal weapons. In any event, the regional army must stay on alert against insurgents simply because it is regularly targeted by KKBs, especially by those that want to spoil or plunder the military arsenal. ${ }^{75}$

The regional police also work closely with the military police (Polisi Militer Kodam, Pomdam) to prosecute improprieties done by military personnel, ${ }^{76}$ because the Indonesian military is not subject to civil law. ${ }^{77}$ For example, on January 28,2015 , after the police disclosed syndicates within a Kodam that sold ammunition to KKB (Purom Wenda) members, the regional police coordinated with Pomdam to prosecute

${ }^{70}$ Sometimes those feuds make the local news: Elin Yunita Kristanti, “Oknum TNI dan Polisi Bentrok di Papua" [TNI and police members shoot at each other], Viva News, April 28, 2009, http://nasional.news. viva.co.id/news/read/53108-oknum-tni-dan-polisi-baku-tembak-di-papua, accessed May 14, 2015; "PolriTNI Saling Serang, Kaimana Mencekam!" [Police and TNI clash in Kaimana], Kompas, August 22, 2012, http://www.kompasiana.com/nurdinmuhammad/polri-tni-saling-serang-kaimana-mencekam 5517142fa33311b906b6592b, accessed May 14, 2015; and Mohammad Arief Hidayat, "Anggota TNI dan Polri Baku Tembak di Papua" [TNI and police shoot at each other in Papua], Viva News, October 13, 2014, http://nasional.news.viva.co.id/news/read/547596-anggota-tni-dan-polri-baku-tembak-di-papua, accessed May 14, 2015, http://kabar24.bisnis.com/read/20141014/16/264744/polri-vs-tni-salingtembak-di-distrik-pirime-papua, accessed May 14, 2015.

${ }^{11}$ Martin Sihombing, "POLRI vs TNI: Saling Tembak Di Distrik Pirime Papua" [POLRI versus TNI clash in Pirime District Papua], Kabar 24, October 14, 2014.

72 "Di Papua, Ada Latihan Gabungan untuk Cegah TNI dan Polri Bentrok Lagi" [In Papua, the police and military conduct combined training for reconciliation], Kompas, November 6, 2014, http://regional.

kompas.com/read/2014/11/06/03380811/Di.Papua.Ada.Latihan.Gabungan.untuk.Cegah.TNI.dan.Polri. Bentrok.Lagi, accessed May 14, 2015.

${ }^{73}$ Interview with the Papua Regional Police's chief of operation bureau, at the police headquarters, Jayapura, April 7, 2015.

${ }^{74}$ This happened in Yaneng Kalome, Tingginambut District, Puncak Jaya Regency; see Dirintelkam Polda Papua, Hakekat Ancaman KKB dan KKP di Papua Tahun 2015, 11.

75 Idid., 10.

${ }^{76}$ Interview with a regional police officer, Jayapura, April 7, 2015.

77 Institute for Policy Analysis of Conflict (IPAC), “The Expanding Role of the Indonesian Military," IPAC Report 19 (May 25, 2015): 7. 
the military personnel involved. ${ }^{78}$ This highlights that, while the turf battle between the police and military continues, TNI and POLRI relations at the regional level are also complementary and cooperative.

Expanding the police force's influence and presence goes beyond assuming duties previously reserved for the army. The expansion also involves increasing the size of the police force, especially its geographical reach. This idea echoes the goal of having Papuan police be as visible as possible in many different geographical settings as the "hold" component of Indonesia's "hold and build" counterinsurgency strategy, discussed next. These efforts also conform to the counterinsurgency tenet of letting locals have ownership of the fight, thereby increasing the legitimacy and effectiveness of counterinsurgency operations.

\section{Indonesia's "Hold and Build" Strategy}

The relationship between people's sympathy for counterinsurgents and the effectiveness of security personnel to quell insurgents is more vexing than it might appear. Although a strong presence of police can provide physical security against insurgents, it does not ensure that the counterinsurgents are considered "legitimate" in the eyes of the people being protected. For example, in Papua, longstanding militarization has fueled an antigovernment narrative rather than eliciting support for the police or military. As explained by David Fidler, although it is essential for counterinsurgents to strengthen the operational capabilities of domestic police forces-such as by force expansion, functional specialization, and improved interagency coordination-the more enduring reformation of the police is conceptual (e.g., winning hearts and minds), which includes promoting close links between the police and local communities. Further, the simultaneous coordination between policeled efforts and the political support of establishment and other government agencies, such as the military, intelligence, and justice, is also imperative. ${ }^{79}$ By implementing a "hold and build" strategy, Indonesian officials hope to accomplish all of that.

\section{Jokowi's Approach}

Responding to emerging internal security threats in West Papua, Jokowi has pledged special attention to insurgent activities by intensifying a three-pronged localized approach to welfare, security, and dialog. This method somewhat resembles former President Yudhoyono's welfare approaches. ${ }^{80}$ However, Jokowi seeks to

\footnotetext{
${ }^{78}$ Rivando Nay, "Jual Amunisi ke OPM, 5 Anggota TNI Terancam Hukuman Mati” [Selling ammunition to the OPM, 5 TNI members threatened to be charged with capital punishment], Sindo News, January 29, 2015, http://daerah.sindonews.com/read/957653/26/jual-amunisi-ke-opm-5-anggota-tni-terancamhukuman-mati-1422544051, accessed May 14, 2015.

${ }^{79}$ Fidler, "Police in Counterinsurgency," 331-332.

${ }^{80}$ During Yudhoyono's presidency, the approach to Papua, to a large extent, placed attention on fostering economic development (pendekatan kesejahteraan) or on welfare approaches. For example, in 2011 , Yudhoyono launched the Unit for the Acceleration of Development in Papua and West Papua (UP4PB), which mainly focused on accelerating the growth of local economies. In 2013, following a meeting between Yudhoyono and Papuan local leaders, he also started discussions to create Otonomi Khusus Plus (Special Autonomy Plus), which sought to modify 2001's failed Special Autonomy Status program, which was unsuccessful in improving the welfare of locals. Nonetheless, there was much resentment from
} 
increase the intensity of and reinvent several elements within each of the pillars. In terms of improving regional welfare, many Indonesian economic development policies have worsened local conditions, such as the notably unsound transmigration policies during the New Order era that created situations whereby urban areas were inhabited mainly by non-Papuans and rural areas mainly by native Papuans, thus exacerbating conflict to new levels. ${ }^{81}$ Hence, the Jokowi administration seeks to introduce several new features for development in West Papua: building infrastructure to reduce the cost of producing goods in order to accelerate the growth of local economies; ${ }^{82}$ providing affirmative attention to native Papuans (e.g., hiring more native Papuans as employees in local government agencies); and introducing measures to ensure fairness and proportionality in resource-sharing between Jakarta and Papua. ${ }^{83}$

To ensure the success of his initiatives, Jokowi realized that the trust of the people towards the government should be cemented. The failure of past governments to acknowledge that the problem with insurgents was more than just economic meant that the policies prescribed were unable to properly address the problems. Not to mention that the widespread notion among central government leaders that Papua is a backwards society which only requires welfare contributed to the indifference toward the political, ideological, and historical nuances of the conflict. Despite POLRI's best efforts to provide security, the inability of the post-Reformasi central government to pursue economic development with fairness and to prosecute the perpetrators of human-rights abuses has created a major impediment for Papuans to forgive and move forward. ${ }^{84}$ Actual experience shows that the influx of national military forces to counter insurgents tends to be viewed favorably for only a short time. Over time the military's legitimacy tends to deteriorate without sufficient top-down assistance in terms of political support from the central government to build the capacity of local governments to improve their performance by addressing human resources, logistical, institutional, and other constraints.

In late 2014 Jokowi's administration promised to resume a dialog to comprehensively address issues that go beyond underdevelopment. ${ }^{85}$ Furthermore, on

Papuans toward Yudhoyono, as he seemed too preoccupied with other international issues rather than listening to people's aspirations or giving sufficient attention to addressing the escalating tensions in Papua. Some analysts have also suggested that Yudhoyono's approach was merely a disguise to further advance the military presence in Papua. See: Hipolitus Yolisandry Ringgi, "Papua's Response to the Gift of Special Autonomy Plus," Open Democracy, January 9, 2014, https://www.opendemocracy.net/hipolitusyolisandry-ringgi/papua\%E2\%80\%99s-response-to-gift-of-special-autonomy-plus, accessed October 25 , 2016; and Theresia Fransiska Tekege, "Imparsial: Janji Dialog dengan Papua dari SBY Belum Terwujud" [Imparsial: SBY's promise to dialog has yet to happen], Majalah Selangkah, February 7, 2014.

${ }^{81} \mathrm{Jim}$ Elmslie, "West Papuan Demographic Transition and the 2010 Indonesian Census: 'Slow Motion Genocide' or Not?" CPACS Working Paper No. 11/1 (2010).

82 Syailendra, Papua Region under Jokowi.

${ }^{83}$ See: Putri Papua, "Ini Agenda Presiden Jokowi di Papua 8-11 Mei 2015" [Jokowi's schedule in Papua from 8 to 11 May 2015], Majalah Selangkah, May 5, 2015; and Yermias Degei, "Mengawal 10 Inisiatif Baru Jokowi untuk Papua Versi Velix Wanggai?" [Jokowi's 10 initiative for Papua], Majalah Selangkah, April 5, 2015.

${ }^{84}$ Sally Andrews, "Papua's Hidden Past Haunts Jokowi Presidency," The Diplomat, January 24, 2015, http://thediplomat.com/2015/01/papuas-hidden-past-haunts-jokowi-presidency/, accessed May 14, 2015. 85 "Jokowi Janjikan Dialog di Papua" [Jokowi promised a peace dialog to be held in Papua], Republika, December 29, 2014, http://www.republika.co.id/berita/koran/politik-koran/14/12/29/nhbv8f2-jokowijanjikan-dialog-di-papua, accessed May 14, 2015. 
April 21, 2015, Jokowi's administration concluded a commitment to set up a team to investigate gross human right violations in the past. ${ }^{86}$ Jokowi also attempted to gain trust from international audiences, especially that of MSG members who have grown pessimistic about Indonesia's inability to address peacefully the Papuan problems. Jokowi started his diplomatic outreach ventures by visiting President O'Neill of Papua New Guinea on May 12, 2015, to express his willingness to build strong ties with PNG, the MSG, and throughout the broader Pacific region..$^{87}$ Indonesia's overtures to the MSG were also successful, which allowed provinces with large Melanesians populations (e.g., Papua, West Papua, Maluku, North Maluku, and East Nusa Tenggara) in Indonesia to participate in cultural, trade, and investment engagements with other members of MSG as Indonesia's representatives, not as representative of OPM. This also helped to water down MSG members' diplomatic support for West Papua's independence. On another front, Jokowi attempted to appeal to a broader international audience by granting clemency to five political prisoners and ending Indonesia's decades-long restrictions on international media access to Papua. ${ }^{8} \mathrm{His}$ goal is to show that the Indonesian government plans to embrace democratic principles in its strategy to hold sovereignty over West Papua. The future effectiveness, efficacy, and sustainability of the government's various promises, however, remain to be seen.

\section{Repositioning the Idea of Police}

In terms of security-building, Jokowi seeks to implement comprehensive measures, both hard and soft, by increasing military representation in Papua as well as improving links between state security agencies and local inhabitants. Indonesian officials realize that winning the support of an aggrieved or fearful population requires a neutral and reliable police force. This is part and parcel of Indonesia's hold-and-build strategy in Papua.

In addition to expanding the geographical scope of regional police as explained above, the Indonesian government is attempting to foster operational and conceptual reforms to increase police effectiveness and legitimacy in counterinsurgency efforts. First, the government has created functional specializations within the police force and is continuously improving its operational effectiveness. For example, the Papuan Police Force now has a specialized unit called the Counterinsurgency Taskforce (Satgas Penanggulangan Separatis). The taskforce is responsible for continuously

86 "Pemerintah Bentuk Tim Usut Kasus Pelanggaran HAM Berat" [Indonesian government formed a team to investigate human right abuse], Kompas, April 21, 2015, http://nasional.kompas.com/read/2015/ 04/21/16195381/Pemerintah.Bentuk.Tim.Usut.Kasus.Pelanggaran.HAM.Berat, accessed October 16, 2015.

87 "Jokowi makes state visit to PNG," The Jakarta Post, May 11, 2015, http://www.thejakartapost.com/ news/2015/05/11/jokowi-makes-state-visit-png.html, accessed May 15, 2015.

${ }^{88}$ See: Mega Putra Ratya, "Ini 5 Tahanan Politik Papua yang Bebas setelah Dapat Grasi Jokowi" [5 political prisoners were granted pardon by Jokowi], DetikNews, September 5, 2015, http://news.detik. com/berita/2910630/ini-5-tahanan-politik-papua-yang-bebas-setelah-dapat-grasi-jokowi, accessed October 16, 2015; and Alfian Kartono, "Presiden Jokowi Resmi Nyatakan Papua Bebas untuk Peliputan Media Asing" [Jokowi declared Papua is open for foreign media coverage], Kompas, May 10, 2015, http://regional.kompas.com/read/2015/05/10/15540221/Presiden.Jokowi.Resmi.Nyatakan.Papua.Bebas. untuk.Peliputan.Media.Asing, accessed May 15, 2015. 
mapping and tracking insurgents' activities. Second, the police force has increased its interagency coordination with the military and other security agencies. Third, the government is attempting to reframe the public perception of the proper role for police in society while realigning police tactics to be fair and within the rule of law.

The regional police reform in Papua has focused on integration with the community. The regional police force has been advancing soft measures, including a special program focusing on rallying public support called "society empowerment," or Bhakti Bina Keamanan dan Ketertiban Masyarakat (Bhabinkamtibmas). This program aims to bring police functions and personnel into community activities. Police officers have worked on various social programs related to health and civic education, as well as joint activities between police and local inhabitants. For instance, in Merauke, the police conducted various agricultural activities in order to reach out to local inhabitants. The police also gained a presence in the town's church network when an officer became one of the preachers. ${ }^{89}$ These integration efforts highlight the overarching objective of counterinsurgency programs: the police force needs to be competent at finding insurgents who blend into local communities while also assuring the general population that it is being protecting from the threat of insurgencies.

In Papua, the regional police are planning to enhance its Bhabinkamtibmas program with a four-prong strategy: shepherd police (polisi gembala), who will work through religious or church networks to counter the development of ideology; teacher police (polisi guru), who will conduct civic education related to Indonesian nationalism; pioneer police (polisi pionir), who will work with Papuans to initiate social and economic projects; and health police (polisi kesehatan), who will attempt to spread awareness regarding health issues such as lung cancer, HIV/AIDS, and other common diseases. Such social empowerment programs have not been fully implemented; however, some have been sporadically initiated to test their effectiveness. ${ }^{90}$ Indigenous police are eager to innovate and immerse themselves within Papua's populations. This immersion is important to enhance the police's capability for data-gathering and threat-mapping, and for early detection and prevention of conflicts.

Among the challenges in implementing empowerment programs are the lack of granular knowledge of the local population and terrain, and in fitting in to multiethnic and multi-lingual areas. To address this issue, the police initiated a program called Brigadir Putra Daerah (Local Youth Brigade), a collaboration with local governments to recruit police from local populations. Since 2008, the effort has recruited more than fifteen hundred Papuans into the force. ${ }^{91}$ This approach is important to address the cultural misunderstanding that has become one of the major causes of tension between the security apparatus and local inhabitants. This push to make the police force more inclusive, and composed of people from the communities they are policing, is also important to enhancing the legitimacy of the police integration program. This is to reverse past dynamics that created much animosity between locals and police personnel. For example, the police used to come predominantly from outer islands, such as Java, Sumatra, and Sulawesi, and were

${ }^{89}$ Interview with the Papua Regional Police's director of intelligence and security, at the police headquarters, Jayapura, April 7, 2015.

90 Ibid.

91 Ibid. 
often predisposed to believe that "Orang Papua bodoh," the Papuans, were backward. ${ }^{92}$

\section{Militarization of Conflict}

While increasing its regional police capability, Indonesia seeks concurrently to increase military representations in the region as well. Indonesia's overreliance on the military has several causes, including the police's inability to curtail insurgent activities. The increasing number of cases of police personnel being killed by insurgents and the internationalization of the conflict shows that the hostility is beyond a mere law-and-order problem. This realization has led government officials to use paramilitary and military forces to combat the insurgents, rather than rely just on the police. The army has confirmed its plan to accelerate the establishment of a Kodam in Manokwari, West Papua province, while the Eastern Region Fleet (Pangkalan Utama Angkatan Laut Armada Indonesia Kawasan Timur, Lantamal Armatim) command base is being shifted to Sorong. The Indonesian military has also been planning to set up the 3rd Division of the Army Strategic Command and the 3rd Division of Air Force Operational Command in Sorong. ${ }^{93}$ It is estimated that 45,000 troops are presently deployed in Papua, and an extra 650 soldiers patrol near the PNG border. With the further expansion of TNI's territorial structure and hosting the Eastern Central Fleet in Sorong, an estimated seven- to ten-thousand new military personnel will be added to the region. ${ }^{94}$ This will significantly increase military representation in Papua.

The surge of militarization highlights that the Indonesian government will take extreme measures to ensure that Papua stays within its sovereignty. The militarization, however, often interferes with the policing efforts that the government of Indonesia attempts to promote. The resulting tensions undermine the police's legitimacy with the population and effectiveness against insurgents. Frequent cases of human rights abuses committed by paramilitary and military forces damage the efforts to increase the Indonesian government's legitimacy in the eyes of the people. ${ }^{95}$

To overcome such problems, the military has started to reposition its image among the population. The military has initiated a civic mission program in Papua by mobilizing Babinsa, who are mostly native Papuans, to carry out the mission. For

92 This sentiment can be seen in Tempo's interview with Lukas Enembe, governor of Papua Province. In this interview, Enembe explained that those in the central government often perceive Papuans as backward and often implement policy arbitrarily without prior consultation with locals. See "Gubernur Papua: Belum Ada Orang Papua Berjiwa Indonesia [Papuans are yet feeling Indonesian]," Tempo, January 10, 2016, http://m.tempo.co/read/news/2016/01/10/078734620/gubernur-papua-belum-ada-orangpapua-berjiwa-indonesia, accessed October 25, 2016.

93 Syailendra, Papua Region under Jokowi.

${ }^{94}$ Interview with TNI officers at Lantamal VI, Sorong, West Papua provinces, Indonesia, March 10, 2015.

${ }^{95}$ For example, on September 4, 2015, students from the Papuan Students Alliance were on the street to demand that President Jokowi prosecute military personnel who were involved in abducting, torturing, and killing local civilians in August 2015. The students also demanded that the military be withdrawn from Papua region. Eko Widianto, "Mahasiswa Berdemo Tuntut Jokowi Tarik Militer dari Papua" [Students demand Jokowi to withdraw the Indonesian military from Papua], Tempo, September 4, 2015, https://m.tempo.co/ $/ \mathrm{read} /$ news/2015/09/04/078697785/mahasiswa-berdemo-tuntut-jokowi-tarikmiliter-dari-papua, accessed October 16, 2015. 
example, the army is setting up Posko Ketahanan Pangan (Post of Food Self-Sufficiency), which will be under the coordination of territorial resistance units. ${ }^{96}$ Some activities have already been implemented by the Kodam units, such as planting and harvesting paddy. TNI's entire social empowerment program was not the end, but merely a means to achieve grass-roots support in favor of the military and against insurgent groups. ${ }^{97}$ The efficacy and sustainability of civic mission programs in Papua, however, remain to be seen. ${ }^{98}$

The explanations above reflect the enduring nature of counterinsurgency operations, which require coordination among stakeholders and consistent implementation. It can be seen that the police force's limitations, growing interference from the military, and lack of political support from Jakarta has thus far undermined police legitimacy in the eyes of local populations. This reality helps explain why the Papuan regional police, despite multiple efforts, contributed little to the positive counterinsurgency results.

\section{Aman Matoa: Strategic Interaction between POLRI and TNI}

Ensuring grass-roots support for counterinsurgency efforts has pushed the army and police to cooperate despite their underlying turf battles over "who's in charge" with regard to national security in Papua. The counterinsurgency operation called Aman Matoa has been led by the Counterinsurgency Task Force (Tim Khusus Penanggulangan Separatis, Timsus) of the Papua Regional Police since 2010. The operation seeks to combat the perceived threat from KKB insurgents (as previously described). ${ }^{99}$ The creation of Timsus reveals the efforts undertaken to fine-tune regional police capabilities to be able to effectively perform diverse functions during operations. ${ }^{100}$

The Aman Matoa operations have several basic principles: early detection of potential sources of conflict, preemptive and preventive measures to hinder the growth of an internal security threat, and comprehensive problem-solving through

${ }^{96}$ For instance, "Kodim 1704/Sorong Membangun Posko Ketahanan Pangan" [Military district command in Sorong building a post of self-sufficiency], Koramil, March 26, 2015, http://koramil.net/home/?p= 8072, accessed May 15, 2015.

${ }^{97}$ Syailendra, Papua Region under Jokowi.

${ }_{98}$ At the national level, various civic-mission programs appear to have positioned the Indonesian military as a popular institution in the eyes of Indonesian citizens, trailing behind the popularity of the president and the Corruption Eradication Comission (KPK). This is indicated by the 2015 Indobarometer survey from thirty-four provinces in Indonesia that noted the TNI has an 81 percent favorability rating. See Fidel Ali, "Survei: KPK, TNI, dan Presiden Peroleh Kepercayaan Publik Tertinggi” [Survey: KPK, TNI, and president gained the highest public trust], Kompas, October 10, 2015, http://nasional.kompas.com/ $\mathrm{read} / 2015 / 10 / 10 / 09314551 /$ Survei.KPK.TNI.dan.Presiden.Peroleh.Kepercayaan.Publik.Tertinggi, accessed October 16, 2015.

${ }^{99}$ Interview with Papua Regional Police's chief of operation bureau, at the police headquarters, Jayapura, April 7, 2015.

${ }^{100}$ As explained by Fidler, “... [s]pecialization makes police actions more proportional and discriminate to the different tasks at hand, which moves police capabilities away from blunter, less flexible, and more indiscriminate approaches associated with militarization of COIN campaigns. Honing these different capabilities allows counterinsurgents to take down insurgents while reducing collateral kinetic and perceptual damage among the population." Fidler, "Police in Counterinsurgency," 336. 
sociological and anthropological approaches. ${ }^{101}$ Timsus's framework for thinking about militant groups divides each group into four layers based on members' convictions: radical leaders at the core, militants as the second layer, then supporters, and sympathizers at the outermost layer. Each layer was considered and approached differently: with law enforcement targeting for the core layers, and hearts and minds attitude changing work directed at the sympathizers, supporters, and, if possible, the militant layer. Therefore, there are short- and long-term goals. The short-term goal is to restore law and order and curtail the militant groups' criminal activities. Hence, the immediate priorities are to conduct threat-mapping and data-gathering pertaining to a group's criminal intent and firepower, pattern of actions, and criminal history; and knowing how large a group is and identifying its members. Enforcing the law is the next immediate objective. The long-term goal of the operation is to rally societal support for the police force and to forge cooperation between locals and the security apparatus (e.g., such that people may be willing to provide intelligence and reports of suspicious activities in their localities). ${ }^{102}$

POLRI's counterinsurgency strategy (Giat Ops) has four prongs: law enforcement (penegakan hukum, gakkum), intelligence (intel), societal empowerment (bimbingan masyarakat, bimmas), and opinion-making or propaganda. ${ }^{103}$ The first and second strategies are low-profile operations that involve covert activities. The first strategy is to enforce the law especially with regard to the core leadership of KKBs. The operation engages the community within the law-enforcement process by involving local governments, the military, and civic partners such as religious figures and village chiefs. The operation is conducted continuously and simultaneously by Timsus's smaller branches, called Law Enforcement Task Force (Satuan Tugas Penegakkan Hukum, Satgas Gakkum), which adopt the minimum (proportional) force principle. ${ }^{104}$ With the use of information and technology within the criminal investigation process, threat-mapping has also become easier to achieve. A local IT analyst team at the Papua Regional Police was set up, and cooperated with the IT team at Jakarta. ${ }^{105}$

The second strategy uses intelligence gathering to strengthen early detection capabilities. This action is conducted primarily by the Intelligence Gathering Task Force (Satuan Tugas Penggalangan Intelijen, Satgas Gal Intel). The operation has two objectives: data gathering via human intelligence, to support both law enforcement operations against radical insurgent groups, and the cultural work of moderating the mindset of supporters. ${ }^{106}$

101 Polda Papua [Papua Regional Police], Strategi Penanggulangan Konflik Dalam Rangka Harkamtibmas [Strategy to overcome conflict in order to keep civilians' security and order] (Jayapura: Polda Papua, 2013), 9.

102 Ibid.

103 Ibid., 10-13.

${ }^{104}$ Interview with local police officer, a member of Timsus, Jayapura, April 8, 2015.

105 Papua Regional Police also place particular importance on strengthening its capabilities for intelligence-gathering and analysis. This is because, under the rule-of-law approach, the successful operation requires that police exploit actionable intelligence. This intelligence capability comes from many different policing functions - from developing networks of informants, increasing interface with local populations, and enhancing technical expertise to improve surveillance capacity.

106 Polda Papua, Strategi Penanggulangan Konflik Dalam Rangka Harkamtibmas, 10. 
The third and fourth strategies are high-profile, visible operations. The third strategy stresses societal empowerment to rally support and cooperation among the people for intelligence-gathering and to prevent the spread of ideologies. These actions are conducted primarily by the Societal Empowerment Task Force (Satuan Tugas Bimbingan Masyarakat, Satgas Bimmas). ${ }^{107}$ The operation specifically targets the KKBs' sympathizers and support networks. The later strategy of opinion-making, or propaganda, seeks to construct favorable public opinion about counterinsurgency measures in order to water down any negative media coverage, and to counter the insurgents' own narrative. This phase of the operation is conducted by a Propaganda Task Force (Satuan Tugas Bentuk Opini, Satgas Bentuk Opini). ${ }^{108}$

In the fifth phase of Aman Matoa, between November 1 and December 30, 2014, the operation was dominated by the local police force: 605 police personnel participated, with 163 army personnel as supporting elements. It was led by Timsus and supported by fifteen local police forces, Kodam XVII/Cendrawasih, the national police force, and state intelligence agency. ${ }^{109}$ During the preparation process, joint exercises were conducted at Kodam XVII/Cendrawasih's training ground (Resimen Induk Kodam, Rindam) and involved Brigadier Mobile personnel, infantry, directorate of criminal detective, directorate of security and intelligence, and air police (Badan Pemeliharan Keamanan, Baharkam Polri). The army's involvement was requested by the police, primarily to help capture the guerrilla forces in the dense and mountainous forests. Therefore, during the exercises, guerrilla training was emphasized, as well as helicopter-jump skills, considering the operation would be waged in the mountains. ${ }^{110}$

The diverse goals created different targets: law-enforcement activities targeted several KKBs and individuals associated with criminal activities, such as supplying insurgents with arms, ammunition, and training. ${ }^{111}$ The intel and bimmas teams targeted several Separatist Political Movement groups (Gerakan Separatist Politik), such as Presidium Dewan Papua (PDP) and West Papua National Authority (WPNA); and movements to support the Free Papua Movement, such as Papua Middle Mountain Student Alliance (Aliansi Mahasiswa Pegunungan Tengah Papua Independen, AMPTPI), Papuan Student Independent Forum (Forum Mahasiswa Papua Independen, FMPI), and any people associated with those movements, such as religious leaders or village chiefs. ${ }^{112}$

The operation started with bimmas and intel operations and continued with propaganda efforts, which was intended to develop contacts on the ground. ${ }^{113}$ To accomplish that, several activities were initiated, such as morning coffee sessions and various meetings for religious leaders (tokoh agama, toga) and societal figures (tokoh masyarakat, toma). The Papua Regional Police was also involved in many social

\footnotetext{
107 Ibid., 11.

108 Ibid., 12.

109 Polda Papua [Papua Regional Police], Paparan Anev "Aman Matoa V-2014" [Aman matoa V 2014-Post operation report] (Jayapura: Polda Papua, 2014), 22-29.

110 Interview with TNI officer at Rindam XVII/Cendrawasih, April 6, 2015.

111 Polda Papua, Rencana Operasi Aman Matoa, 14-22.

112 Ibid.

113 Polda Papua, Paparan Anev “Aman Matoa V-2014," 30-35.
} 
engagement activities, for instance, taking part in traditional Bakar Batu ceremonies ${ }^{114}$ and promoting social projects (e.g., free health clinics and sports activities, such as soccer and volley competitions).

The second wave of operations was conducted by the Law Enforcement Task Force in cooperation with the army to chase down KKB members in the mountains, with a focus on Puncak Jaya and Lanny Jaya. The operations were run concurrently with threat-mapping activities to locate the armed criminal groups. The operation was intensified during several important days for the Free Papuan Movement, when OPM usually conducted its criminals and political activities. ${ }^{115}$

Aman Matoa achieved mixed results. The social-engagement activities were successful, as they provided valuable human intelligence and contributed to obtaining valuable information related to the locations of several KKBs. (Locating the KKBs was valuable for, once the counterinsurgency task force found evidence of a group's criminal activities, law enforcement was able to step in and capture the leaders). ${ }^{116}$ During the fifth phase of Aman Matoa, the criminal activities of several groups were uncovered. For example, on October 26, 2014, the KKBs of Rambo Tolikara and Rambo Wenda, OPM commanders from the Tolikara region, were caught buying ammunition in Wamena and are currently facing trial. ${ }^{117}$ Some operations were successful owing to the assistance provided by the army. Chasing down KKB members in the mountainous region of Papua, with its difficult terrain and access, required the guerrilla-warfare infiltration capability of the Indonesian army. On November 27, 2014, the combined police-military operation chased down Fernando Arobai in Yapen, Papua, and recovered evidence of KKB activity, such as ammunition and weapons and uniforms and accessories associated with separatist insignias. ${ }^{118}$ On December 9, 2014, the Counterinsurgency Task Force, supported by army personnel, was able to regain the weapons that had been looted by the West Papua Liberation Army group from air force personnel on November $15 .{ }^{119}$

The explanations above have demonstrated not only that the police force learned to conduct successful interagency operations, but also the success of promoting the specialization of police functions to meet diverse counterinsurgency goals and multivariate challenges presented by the insurgents. The regional police created relatively sophisticated specialization themes, including various special units to separate the Criminal Investigation Division (ordinary crime) from the Special Branch (insurgency-related crime). The police have also taken into consideration cultural and religious elements to counter OPM propaganda to enhance integration efforts.

\footnotetext{
${ }^{114}$ Bakar Batu [Burning Stone] is one of the most important Papuan traditional ceremonies. It is a form of communal cooking on a heated stone that strengthens communal bonds. Interview with the Papua

Regional Police's director of intelligence and security, at police headquarters, Jayapura, April 7, 2015.

This was confirmed during an interview with a local informant, Jayapura, April 6, 2015.

115 Polda Papua, Paparan Anev “Aman Matoa V-2014," 36-41.

116 Interview with of the Papua Regional Police's director of intelligence and security, at the police

headquarters, Jayapura, April 7, 2015

117 Polda Papua, Paparan Anev “Aman Matoa V-2014," 42.

118 Ibid., 45.

119 Ibid., 47.
} 


\section{The Police as Counterinsurgents, Part of the Solution?}

It can be seen that Indonesia's transition to democracy has influenced the way it handles OPM. The political transition has been followed by multiple efforts to strengthen the police force as a counterinsurgency participant in Papua. This situation has led to the police becoming more central to the Indonesian government's strategy and tactics against insurgents. The shift of counterinsurgency operations to the police was driven by the political consideration to protect civilians' rights via the rule of law and to professionalize the military, which was overtly involved in civilian affairs during Suharto's authoritarian regime. Hereinafter, Indonesia's counterinsurgency practices have reoriented to adopt population-centric operations, with the goal of gaining public support so people will be willing to cooperate by providing intelligence and assisting law enforcement.

This shift in counterinsurgency philosophy, however, came with several consequences. First, the asymmetric situation, where the police force has to abide by the rule of law, while the insurgents can violently respond to the security apparatus, often creates frustration among security personnel. This shortcoming can motivate some police officers to use heavy-handed measures in response to the activities of the insurgents. This situation is also exacerbated by insurgents' strategy of combining violent and nonviolent tactics, which, in a democratic system, requires the police to suppress peacefully the former while permitting the latter. Second, the shift also requires the security apparatus not only to undertake operational reform to enhance effectiveness, but also conceptual reform to better position its image in the eyes of the populace. The dilemma is that the two reformations at times conflict, as the escalation of power often brings with it negative repercussions regarding the image of security personnel in the eyes of local inhabitants. As portrayed above, in the midst of the war of narrative, a strong military reaction serves to feed the antigovernment narrative.

This study also illustrates the extent of reform that the regional police have achieved and its future trajectory. It can be observed that the regional police have shown the ability to evolve over the duration of a campaign, especially in terms of strategies to rally support from the local inhabitants. The regional police have enhanced their operational effectiveness by creating functional specializations within the police force. Since 2010, the Papua Regional Police has been able to create a specialized body called the Satgas Penanggulangan Separatis. During the Aman Matoa operation, it was also shown that the police were able to create further specialized units, such as Satgas Gakkum, Satgas Gal Intel, Satgas Bimmas, and Satgas Bentuk Opini. This highlights the ability of the police to be internally flexible. Moreover, specialization is especially important to improve operational effectiveness.

Further, the police have demonstrated an ability to integrate themselves into the community. They have also recruited local inhabitants to address the lack of cultural knowledge, and they have carried out many innovations in their social engagement activities. For example, during Aman Matoa, the police carried out social engagement activities that placed important emphasis on the socio-cultural aspect, especially in terms of building trust with religious and societal figures and attending important traditional ceremonies, such as the Bakar Batu. Such "friendly policing" has the added benefit of encouraging communities to sever their links with insurgents, thus reducing 
insurgents' base of support. It can be seen that the regional police force has been able to yield significant results in terms of actionable intelligence from the operation.

Despite the overall success of the joint police-military operation, the broader strategy has yet to show decisive success in curbing the Free Papua Movement. As previously explained, insurgency movements are abetted by a combination of factors, including the lack of functioning police forces; dysfunctional behavior by the security apparatus, which ultimately fuels the insurgency; and insufficient support from political, economic, and cultural actors. Those shortcomings are exacerbated by security forces' ethnocentric tendencies that interfere with the overall rule-of-law approach. For example, the local police still frequently condone the use of derogatory terms toward locals and the practice of racial profiling to identify OPM members solely on the basis of skin color and domicile. Various social empowerment programs launched by security agencies are also still driven by a perception of "local inability" rather than "local partnership," and a condescending perception, borne of years of ingrained prejudice, that the locals are backward. With such attitudes, a social empowerment program-even one based on a sound rationale-can descend into a situation where those running the program resort to intimidation to deal with shortterm pressures. Consider, too, that the central government tends to disregard the importance of prosecuting perpetrators of human-rights abuses in Papua, instead insisting that economic development alone will be sufficient to gain support from the locals.

To enhance the legitimacy of police reform in the eyes of local inhabitants, comprehensive reshaping on the political, security, justice, and economic fronts is imperative. This is because, under the population-centric approach, legitimacy in the eyes of the population seems to be what determines the victor in the war of narratives between insurgents and counterinsurgents. This thinking also mandates that the Indonesian government find a way to enhance security agencies' operational effectiveness while concurrently strengthening their political legitimacy. Therefore, the hold-and-build strategy should not be restricted to developing the local economy and bolstering the presence of TNI and POLRI in Papua. It has to be accompanied by a strong political will to listen to people's aspirations with regard to what they believe are the fundamental building blocks for sustainable peace in Papua. 